\title{
De aanpak van belastingontwijking door de EU: gerichte maatregelen zonder structurele verandering.
}

\author{
Indra Römgens ${ }^{*}$
}

\section{Introductie}

Op 27 november 2018 kwam in het Europees Parlement (hierna: Parlement) de Bijzondere Commissie financiële misdrijven, belastingontduiking en belastingontwijking bijeen voor een overleg met Eurocommissaris Pierre Moscovici. Moscovici is binnen de Europese Commissie (hierna: Commissie) verantwoordelijk voor economische en financiële zaken, belastingen en douane. Tijdens het overleg werd teruggekeken op de aanpak van belastingontwijking in de afgelopen jaren. Volgens de Eurocommissaris was daar de laatste vier jaar (onder zijn bewind) meer aan gedaan dan in de twintig jaar daarvoor. Sven Giegold, Duits Europarlementariër voor de Groenen, bevestigde dit: 'We kunnen eerlijk zeggen dat er op geen enkel EU wetgevingsgebied zo veel vooruitgang is geboekt als op het gebied van belastingen en anti-witwassen' (Europees Parlement, 2018a). 'Desondanks...', zo begon hij de volgende zin, 'kunnen Europese burgers nog niet tevreden zijn.' Giegold vervult nu zijn tweede termijn voor de Groenen in het Parlement. In 2002 was hij medeoprichter van het internationale Tax Justice Netwerk.

De in deze woordenwisseling doorklinkende tegenstelling legt bloot dat de hoeveelheid aan ontwikkelingen in de afgelopen jaren niet per se geëvenaard wordt door een hoge mate van structurele veranderingen. Dat raakt precies de vragen die dit artikel poogt te beantwoorden: wat zijn de belangrijkste beleidsontwikkelingen in de Europese Unie (EU) op het gebied van belastingontwijking door bedrijven, en duiden deze veranderingen op een structurele verandering in EUbelastingbeleid en onderliggende machtsverhoudingen? Dit artikel start met een korte schets van de problematiek van belastingontwijking en de acties die staten ondernamen die tot deze situatie leidden. Vervolgens wordt een overzicht gegeven van de belangrijkste beleidswijzigingen en -initiatieven in de EU op het gebied van belastingontwijking en fiscale transparantie sinds de vorige Europese Parlementsverkiezingen in 2014. Het toont aan dat een aantal gerichte, beperkte maatregelen is aangenomen, terwijl structurele verandering op het EU-belastingbeleid vooralsnog uitblijft. In de vierde paragraaf worden hiervoor verklaringen gezocht in internationale politieke processen, belastingcontroverses en de dynamiek binnen en tussen instituties van de EU.

* MSc Indra Römgens is Promovendus aan de Roskilde Universiteit in Denemarken en de Radboud Universiteit in Nijmegen. 


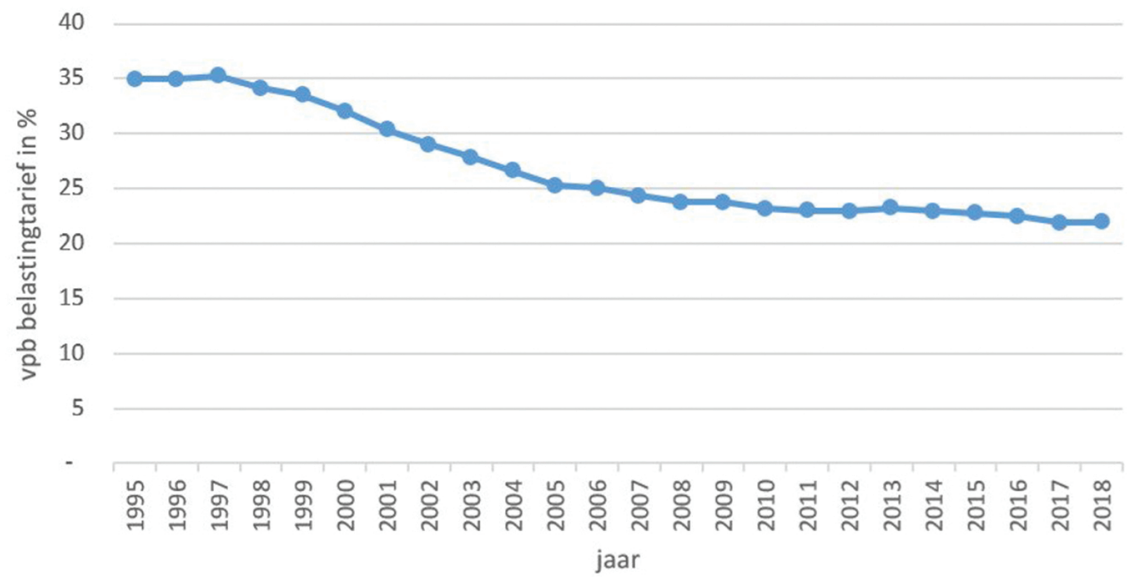

(bron: Europese Commissie, Data on Taxation, https://ec.europa.eu/taxation_customs/business/ economic-analysis-taxation/data-taxation_en, geraadpleegd december 2018

Figuur 1 Hoogste tarieven voor de vennootschapsbelasting in de EU-28, 1995-2018

\section{Context: competitie, samenwerking en ontwijking}

Met het afschaffen van kapitaalcontroles sinds de jaren zeventig zijn de ontwijkingsmogelijkheden voor mobiel kapitaal vergroot (Picciotto, 2011). Samenwerking tussen staten op belastinggebied had hoofdzakelijk het voorkomen van dubbele belasting tot doel (Genschel \& Rixen, 2015). Voornamelijk bilaterale belastingverdragen, vaak gebaseerd op een binnen de Organisatie voor Economische Samenwerking en Ontwikkeling (OESO) ontwikkeld modelverdrag, moesten ervoor zorgen dat grensoverschrijdende bedrijfsactiviteiten niet dubbel belast werden. In deze context van internationale liberalisering - met name door de afwezigheid van kapitaalcontroles - intensiveert belastingcompetitie tussen nationale staten (Devereux, Lockwood \& Redoano, 2008). De aanname dat mobiel kapitaal navigeert tussen lage tarieven, geheimhoudingsregimes, belastingparadijzen en gunstige vrijstellingen, en zo de weg van de minste belasting vindt, ligt ten grondslag aan de theorie van belastingcompetitie en blijkt ook in de praktijk (Bucovetsky, 1991; Genschel \& Schwarz, 2011; Wilson, 1991; Zodrow, 2003; Zodrow \& Mieszkowski, 1986). Deze competitie leidt tot dalende vennootschapsbelastingtarieven (Leibrecht \& Hochgatterer, 2012). ${ }^{1}$ Figuur 1 toont de ontwikkeling van statutaire tarieven in de vennootschapsbelasting in de EU voor de periode 1995-2018. Het gemiddelde vennootschapsbelastingtarief in de EU is gedaald van 35 procent in 1995 naar net onder de 22 procent in 2018.

Het geldende (statutaire) tarief verschilt vaak van het effectieve belastingtarief. Aftrekposten, vrijstellingen en andere belastingvoordelen die door staten worden 
ontworpen, zorgen ervoor dat bedrijven vaak minder belasting afdragen dan verwacht op basis van het statutaire tarief. Bovendien kunnen ze belasting ontwijken. Daarom wordt het statutaire tarief vaak vergeleken met het effectieve belastingtarief. De Commissie berekende dat het effectieve belastingtarief voor bedrijfswinsten is gedaald met 2 procent in de tien jaar na de crisis: van 22,1 procent in 2007 naar 20,1 procent in 2017 (Europese Commissie, 2018a). Dit betekent niet noodzakelijkerwijs dat de opbrengsten uit de vennootschapsbelasting in de verschillende EU-staten zijn gedaald. Dat is over het algemeen niet het geval geweest, omdat bedrijfswinsten in dezelfde periode stegen.

De daling in belastingtarieven in de EU wordt gespiegeld in mondiale ontwikkelingen. Belastingcompetitie binnen de EU is echter sterker dan tussen EUlidstaten en niet-EU-staten (Davies \& Voget, 2008; Genschel, Kemmerling \& Seils, 2011; Redoano, 2014). Dat is het gevolg van het creëren van een interne markt waarin de kosten en andere barrières voor grensoverschrijdende investeringen en handel zijn verlaagd, en waarin het recht op vrij verkeer voor kapitaal prioriteit heeft boven bescherming tegen uitholling van de belastinggrondslag van lidstaten (Genschel \& Jachtenfuchs, 2011). De EU erkent echter wel dat de effecten van belastingcompetitie ongewenst kunnen zijn. Sinds het eind van de jaren negentig adresseren zowel EU-instituties als de OESO het probleem van zogenaamde 'schadelijke' belastingcompetitie (EU 98 C 2/1) (Radaelli, 1999).

Gerelateerd aan de intensivering van belastingcompetitie zijn het bestaan en de ontwikkeling van belastingparadijzen. Er is geen overeenstemming over wat de definitie van belastingparadijs is, maar 'ideaaltypische' elementen van belastingparadijzen zijn geen tot lage (effectieve) belasting voor buitenlandse entiteiten en personen, geheimhouding, en anderszins het faciliteren van transacties en constructies die ontwijking van belasting en andere regelgeving (vrij naar Palan, Murphy \& Chavagneux, 2009).

In deze context van groeiende belastingcompetitie en een netwerk van belastingparadijzen zijn transnationale ondernemingen in toenemende mate sinds eind jaren zestig in staat geweest de verschillen tussen nationale regels uit te buiten in hun voordeel (Picciotto, 2011). Dat uit zich onder andere in belastingontwijking door deze ondernemingen (en rijke individuen). Gefaciliteerd door het beleid van veel staten, verliest de EU tot duizend miljard euro aan belastingontwijking en ontduiking (Murphy, 2012). De keuzes voor methodologie, definities (zoals van belastingparadijzen) en dataverzamelingen zorgen voor zeer uiteenlopende cijfers die uitdrukking geven aan het schuiven met winsten en het ontwijken van belasting. Bovendien zijn dit vrijwel altijd schattingen wegens de beperkingen en onvolledigheid van publiek beschikbare data betreffende financiële stromen en belastingverplichtingen. Een van de meest recente onderzoeken toont aan dat 40 procent van 'multinationale winsten' kunstmatig verschoven wordt naar belastingparadijzen (Tørsløv, Wier \& Zucman, 2018, 22). ${ }^{2}$ De onderzoekers berekenden dat van de op papier verschoven winsten meer dan een derde uit 'niet-belastingparadijselijke' EU-landen komt. De rol van de belastingparadijzen in de EU is groot: 80 procent van de winsten die kunstmatig verschoven wordt uit 'niet-paradijselijke' EU-landen, gaat naar belastingparadijzen in de EU (Tørsløv e.a., 2018, 25). Kunstmatige winstverschuiving heeft tevens een gedifferentieerd mondiaal 
effect: lage-inkomenslanden, of ontwikkelingslanden, worden relatief harder getroffen dan hoge-inkomenslanden (Crivelli, De Mooij \& Keen, 2015; Jansky \& Palansky, 2017; UNCTAD, 2015).

Samenwerking binnen de EU om de problematiek van belastingcompetitie, -paradijzen en -ontwijking te adresseren is in de afgelopen decennia gegroeid. Echter, de welvaartsverdeling die het gevolg is van deze problematiek wordt onvoldoende aangekaart. Immers, om te compenseren voor verliezen aan overheidsinkomsten als gevolg van belastingcompetitie in de vennootschapsbelasting zijn belastingtarieven op immobiele factoren (voornamelijk arbeid) verhoogd (Bretschger \& Hettich, 2002, 710).

De volgende paragraaf geeft een overzicht van de meest recente beleidsinitiatieven die in de EU zijn ontwikkeld en, in sommige gevallen, aangenomen.

\section{Transparantie en anti-ontwijking: beleidsontwikkelingen in de afgelopen vijf jaar}

Zeven recente beleidsontwikkelingen worden hieronder in twee categorieën besproken: fiscale transparantie en de aanpak van belastingontwijking. ${ }^{3}$

\section{Publieke transparantie en gegevensuitwisseling}

Met het gestegen aantal schattingen van (de gevolgen van) belastingontwijking is ook de roep om meer transparantie gestegen. Het gebrek aan publieke transparantie wordt in toenemende mate geproblematiseerd. De kritiek komt voornamelijk van ngo's en vakbonden, maar sommige nationale overheden erkennen ook dat een gebrek aan informatie de aanpak van belastingontwijking verhindert. Een van de meest besproken vormen van fiscale transparantie is country-by-country $(C b C)$ reporting. Dit omhelst het uitsplitsen van specifieke financiële data per land waar een bedrijf actief is. $C b C$ reporting vergroot beschikbare informatie betreffende de activiteiten die door ondernemingen in verschillende landen worden ontplooid en de eventueel belastbare winsten die er worden gegenereerd. ${ }^{4}$ De Commissie presenteerde in april 2016 een voorstel voor publieke CbC reporting (COM/2016/0198). Het werd gepresenteerd als 'een eenvoudige en evenredige manier om multinationals meer verantwoording te laten afleggen over belastingzaken zonder dat hun concurrentievermogen daardoor verzwakt' (Europese Commissie, 2016a). Een meerderheid in het Parlement steunde dit voorstel en adopteerde amendementen om de reikwijdte van het voorstel uit te breiden. $\mathrm{Na}$ de stemmingsprocedure in het Parlement lijkt er echter weinig tot geen beweging te zitten in dit dossier, als gevolg van onenigheid in de Raad (Europese Raad, 2017). Deze laatste wordt hier direct op aangesproken door de Bijzondere Commissie financiële misdrijven, belastingontduiking en belastingontwijking van het Parlement, die het 'ontbreken van vooruitgang en samenwerking in de Raad sinds 2016 betreurt en erop aandringt dat er vooruitgang wordt geboekt in de Raad zodat deze in onderhandeling kan treden met het Parlement' (Europees Parlement, 2018b). Dit betekent dat, tot op dit moment, er geen triloogonderhande- 
lingen (tussen de Raad, het Parlement en de Commissie) plaatsvinden met betrekking tot dit dossier.

Een voorstel voor meer fiscale transparantie dat wél werd aangenomen, in 2015, vereist gegevensuitwisseling tussen overheden - niet publieke transparantie zoals in het geval van $C b C$ reporting. Het betreft de automatische uitwisseling van bepaalde rulings, of verrekenprijsafspraken (EU 2015/2376), die voorheen alleen op verzoek werden uitgewisseld. Dit zijn schriftelijke afspraken tussen een belastingdienst en belastingbetaler - meestal een bedrijf - over de (toekomstige) toepassing van belastingwetgeving op de situatie van de betreffende belastingbetaler. De uitgewisselde informatie bevat onder andere de naam van de belastingbetaler met wie de ruling is gemaakt en een samenvatting van de 'relevante zakelijke activiteiten of transacties of reeks van transacties' (EU 2015/2376). Het betreft hier rulings die betrekking hebben op grensoverschrijdende transacties en die voorafgaand (en niet achteraf) zijn afgesproken. Echter, de praktijk wijst uit dat rulings 'betreffende fiscaal geïnspireerde structuren' kunnen leiden tot kunstmatig lage belastbare inkomsten van de belastingbetaler in andere betrokken landen ( EU 2015/2376). Het wetsvoorstel tot automatische uitwisseling van grensoverschrijdende rulings was deel van het pakket fiscale transparantiemaatregelen dat de Commissie presenteerde op 18 maart 2015 (Europese Commissie, 2015). In datzelfde jaar, december 2015, werd het wetsvoorstel aangenomen in de Raad.

De automatische uitwisseling van grensoverschrijdende rulings is geen opzichzelfstaande wet, maar een amendement op de Richtlijn wat betreft verplichte automatische uitwisseling van inlichtingen op belastinggebied (Richtlijn 2011/16/EU). Dezelfde richtlijn werd nadien meerdere keren aangepast, onder andere in mei 2018 (Richtlijn 2018/822/EU). Dit recentste amendement verplicht tussenpersonen om fiscale constructies met bepaalde karakteristieken door te geven aan de Belastingdienst, aangezien dit signalen zijn die op belastingontwijking wijzen. Vervolgens wordt deze informatie uitgewisseld tussen belastingautoriteiten in de EU. Het gaat om beroepsgroepen als belastingadviseurs, banken, consultants, accountants. ${ }^{5}$

Onder de noemer van transparantie worden door de Commissie en de EU-lidstaten verschillende zaken geschaard. De twee overeengekomen maatregelen betreffende rulings en belastingadviseurs zorgen voor uitgebreidere uitwisseling van informatie tussen belastingautoriteiten van de EU-lidstaten. De informatie wordt echter niet gedeeld met landen buiten de EU (onder deze richtlijnen), laat staan met een breder publiek. Dit staat in tegenstelling tot publieke $\mathrm{CbC}$ reporting, dat expliciet tot doel heeft transparantie te vergroten ten behoeve van de gehele maatschappij. De actoren die de politieke druk voor meer transparantie hebben vergroot - ngo's, vakbonden, sociale bewegingen -, plukken uiteindelijk niet de meeste vruchten van fiscale transparantie. Vergroting van publieke transparantie stuit in de regel op weerstand vanuit het bedrijfsleven. Zo stelde bijvoorbeeld Business Europe, de grootste lobbyorganisatie van het bedrijfsleven op EUniveau, met betrekking tot het publieke karakter van het $\mathrm{CbC}$ reporting-voorstel van de Commissie dat het een gevaar vormt voor 'de aantrekkelijkheid van de EU als een investeringsbestemming' (Business Europe, 2016). 


\section{EU-maatregelen tegen belastingontwijking en belastingparadijzen}

Decennialang was het voorkomen van dubbele belasting leidend in Europese samenwerking op belastinggebied. Een analyse van de probleemstellingen en daaraan verwante oplossingen in de EU op het gebied van de vennootschapsbelasting in de periode 2003-2017 toont dat de beperkte aandacht voor het voorkomen van dubbele belasting is verbreed met een additionele gerichtheid op het aanpakken van belastingontwijking (Roland, 2018). Deze verschuivingen zijn vooral te zien na 2013, na de start van de mondiale kredietcrisis en de staatsschuldencrisis in de EU (Roland, 2018, 10). In de context van financiële crises 'resoneren voorstellen om agressieve internationale belastingplanning tegen te gaan met de toenemende politieke eisen voor meer gelijkheid en eerlijkheid in de mondiale economie' (Elbra \& Eccleston, 2018, 3). Op EU-niveau zijn in recente jaren verschillende wetsvoorstellen besproken die gepresenteerd worden als maatregelen om mazen in de wetgeving te dichten, winstverschuiving naar belastingparadijzen aan te pakken, en bedrijven te verplichten hun fair share te betalen. Hier worden vier verschillende beleidsinitiatieven besproken: een richtlijn ter bestrijding van belastingontwijking (Anti-Tax Avoidance Directive, ATAD), de EUlijst van niet-coöperatieve rechtsgebieden voor belastingdoeleinden (ook wel de zwarte lijst van belastingparadijzen genoemd), fair taxation van digitale bedrijfsactiviteiten, en de gemeenschappelijke geconsolideerde heffingsgrondslag voor de vennootschapsbelasting (Common Consolidated Corporate Tax Base, CCCTB).

In de traditie van het presenteren van maatregelen in de vorm van pakketten werd in januari 2016 het Anti Tax Avoidance Package door de Europese Commissie gepresenteerd (Europese Commissie, 2016b). Het voornaamste onderdeel van dit pakket was een wetsvoorstel 'tot vaststelling van regels ter bestrijding van belastingontwijkingspraktijken welke rechtstreeks van invloed zijn op de werking van de interne markt'. Dit voorstel kan niet los worden gezien van het project Base Erosion and Profit Shifting (BEPS) dat in 2013 werd gestart binnen de OESO en dat in 2015 leidde tot overeengekomen maatregelen om het internationale belastingsysteem aan te passen met als doel kunstmatige winstverschuiving en daaruit resulterende uitholling van de grondslag tegen te gaan. De Europese Raad gaf voorkeur aan 'een doeltreffende, snelle en gecoördineerde implementatie op EUniveau van de maatregelen ter bestrijding van BEPS' (EU 2016/1164), aangezien een versplinterde implementatie van de OESO-afspraken het functioneren van de interne markt waarschijnlijk niet ten goede zou komen. Nadat er jaren aan onderhandelingen voorafgingen binnen de context van de OESO, werd het ATAD-voorstel in hetzelfde jaar nog aangenomen als richtlijn (EU 2016/1164).

De ATAD-richtlijn heeft als doel een aantal specifieke mechanismen aan te pakken die, zo is gebleken, veelvuldig gebruikt worden om winsten te verschuiven en zo belasting te ontwijken. Passieve inkomensstromen, zoals rente-, dividenden royaltystromen, worden geleid van hoog belaste naar laag belaste jurisdicties. De richtlijn, bestaande uit vijf maatregelen, heeft als doel, aldus de EU, een aantal van deze gaten te dichten. Zo moet de controlled foreign company-maatregel landen in staat stellen winst te belasten als deze wordt verschoven naar een laag belaste dochteronderneming in het buitenland. Beperkingen op het aftrekken van rente van de belastbare winst moeten interne groepsleningen die voor ontwij- 
kingsdoeleinden worden opgezet aanpakken. Of deze doelstellingen ook werkelijk bereikt worden middels de ATAD-richtlijn is nog de vraag. De richtlijn trad recentelijk, 1 januari 2019, in werking. In het omzetten van de EU-richtlijn in nationale wetgeving hadden EU-lidstaten ruimte om voor een zwakkere of strengere variant van de ontwijkingsaanpak te kiezen. De Nederlandse overheid koos voor het eerste. $^{6}$

Een tweede onderdeel van het anti-ontwijkingspakket is samenwerking op het gebied van beoordeling van 'derde landen', oftewel landen buiten de EU, bij belastingroutes. Sommige EU-lidstaten hanteren een lijst van belastingparadijzen waaraan gevolgen zijn verbonden (zoals het ontzeggen van bepaalde belastingvrijstellingen wanneer duidelijk is dat het betreffende inkomen eindigt in een land op deze lijst). Na deze eerste aankondiging in 2016 werd er een score board ontwikkeld en in december 2017 werd de lijst voor het eerst gepubliceerd. Sindsdien wordt deze regelmatig aangepast op basis van de acties die door de betreffende landen op de lijst wordt genomen (Europese Commissie, 2018b).

In maart 2018 presenteerde de Commissie twee voorstellen om de winst van internetbedrijven te belasten: een korte- en een langetermijnoplossing. De noodzaak om de belastingheffing van precies deze industrie te veranderen werd als volgt duidelijk gemaakt: 'Het gemiddelde effectieve belastingtarief van internetbedrijven is momenteel de helft van dat van bedrijven in de traditionele economie van de EU' (Europese Commissie, 2018c). De voorstellen van de Commissie volgden een oproep van de Franse minister van Financiën, gesteund door zijn Duitse, Spaanse en Italiaanse collega's, in september 2017 om de omzet (en niet de winst) van digitale bedrijven te belasten (Reuters, 2017). Het kortetermijnplan van de Commissie sluit hierbij aan. Het langetermijnvoorstel betreft echter wel het belasten van de winst op basis van een nieuwe, bredere definitie van wanneer bedrijven een 'digitale aanwezigheid' hebben. Het stelt ook een nieuwe manier van winstallocatie voor. Op termijn moet, volgens de Commissie, dit aansluiten bij het de richtlijnvoorstellen voor de geharmoniseerde (geconsolideerde) belastinggrondslag voor de vennootschapsbelasting $(C(C) C T B)$. De voorstellen zijn vanuit veel verschillende hoeken bekritiseerd (zie bijvoorbeeld Becker \& English, 2018). Vooralsnog lijkt het erop dat er geen overeenstemming wordt gevonden binnen de EU en dat verschillende lidstaten in 2019 hun eigen (interim-)maatregelen introduceren (Fortune, 2019).

Het initiatief tot harmonisatie in de directe vennootschapsbelasting werd in 2016 ge(her)lanceerd. Eenheid in belastingsystemen binnen de EU is al sinds de jaren zestig onderwerp van politieke discussie. De belangrijkste doelstelling was het uit de weg ruimen van obstakels voor het tot stand brengen en functioneren van de interne markt, waarbij de nadruk lag op de verschillen tussen nationale belastingsystemen die tot dubbele belasting binnen de EU leidden (Panayi, 2013). Ondanks verschillende rapporten, geschreven door zowel comités van experts als de Commissie zelf, stond een gebrek aan unanimiteit tussen de lidstaten over een veelomvattend Europees belastingsysteem concrete actie in de weg. Pas in 2011 werd voor het eerst een richtlijnvoorstel gepresenteerd (COM(2011) 121/4). Ondersteund door een meerderheid in het Parlement, maar gesneuveld in de Raad, ${ }^{7}$ werd het voorstel in 2016 geherlanceerd in de vorm van twee aparte richt- 
lijnen: een voorstel voor harmonisatie van de belastinggrondslag in de EU (COM(2016)683) en een voorstel voor daaropvolgende consolidatie, inclusief een verdeelsleutel op basis waarvan belastbare winst binnen de EU gealloceerd wordt aan lidstaten (COM(2016)685). Deze twee stappen gezamenlijk vormen een nieuwe en verregaande samenwerking tussen de EU-lidstaten, en een structurele verandering in het belasten van bedrijfswinsten. Een bedrijf wordt in deze situatie belast op basis van de financiële prestaties van de gehele groep, en niet per groepsentiteit zoals nu het geval is (Picciotto, 2012). Er zijn twee doeleinden, aldus de Commissie. Ten eerste het stimuleren van grensoverschrijdende bedrijvigheid door het verlagen van de administratieve lasten (één belastingloket), waarmee het concurrentievermogen van de EU als geheel versterkt moet worden. Ten tweede moeten consolidatie en de verdeelsleutel voor de nieuwe wijze van winstallocatie bijdragen aan de aanpak van 'agressieve belastingplanning', aangezien het de mogelijkheden tot winstverschuiving via verrekenprijzen (zie hierboven) binnen de EU beëindigt. Gezamenlijk moeten deze twee doeleinden bijdragen aan de prioriteit van de EU van 'sustainable growth and investment within a fair and better integrated market' (COM(2016)685). Alhoewel de Commissie het streven naar deze CCCTB niet opgeeft - en wekelijks twittert ten gunste van beide richtlijnvoorstellen -, is het een politieke strijd om hier unanimiteit te bereiken (Van de Streek, 2017). Afgelopen zomer spraken de Duitse en Franse staatshoofden zich expliciet uit in een gezamenlijk 'position paper' voor zowel stap één (harmonisatie) als stap twee (consolidatie en allocatie). ${ }^{8}$

De strategie van de Commissie om de CCCTB op te knippen heeft potentieel grote gevolgen. Lidstaten bespreken momenteel alleen de eerste stap (CCTB). Pas na overeenstemming hierover starten officiële onderhandelingen wat betreft de tweede stap (CCCTB). Het is daarom mogelijk dat slechts het eerste richtlijnvoorstel wordt aangenomen, waarbij bedrijven wel de mogelijkheid krijgen winsten en verliezen binnen de EU met elkaar te verrekenen, en de tweede stap van een nieuwe manier van winstallocatie uitblijft. In die situatie wordt wel grensoverschrijdende bedrijvigheid gestimuleerd (eerste doeleinde, zie hierboven), maar worden mogelijkheden voor 'agressieve belastingplanning', of belastingontwijking, niet ingeperkt (tweede doeleinde). Bovendien is expliciet niet onderdeel van deze voorstellen een binnen de EU vastgesteld minimumtarief voor de vennootschapsbelasting. Dat betekent, in een scenario dat de CCCTB volledig geïmplementeerd wordt in de EU, dat belastingcompetitie tussen lidstaten op het gebied van tarieven blijft bestaan én waarschijnlijk intensiveert.

\section{Deelconclusie}

Een aantal beleidsinitiatieven is na onderhandelingen binnen de EU aangenomen en omgezet in wetgeving. Dit zijn voornamelijk gerichte maatregelen die tot doel hebben specifieke misbruikconstructies aan te pakken of de gegevensuitwisseling voor een bepaalde zaak (zoals rulings) te vergroten. Deze maatregelen hebben effect. Andere voorstellen zijn vooralsnog precies dat: voorstellen. Verdergaande publieke transparantie en een structurele verandering in de manier waarop 
winsten belast worden - of het nu gaat om digitale activiteiten of alle activiteiten van grote multinationals - lijken politiek onhaalbaar. Dat wil zeggen, overeenstemming tussen alle EU-lidstaten in de Raad is tot nog toe niet bereikt. Eurocommissaris Moscovici kan wellicht stellen dat het aantal aangenomen EU-richtlijnen en besproken EU-voorstellen in de afgelopen jaren significant is vergeleken met de periode daarvoor. Op papier is de aanpak van belastingontwijking, naast het voorkomen van dubbele belasting, een belangrijk beleidsdoel geworden. Echter, het heeft vooralsnog nog niet geleid tot structurele verandering in de manier waarop bedrijfswinsten belast worden.

\section{Waarom specifieke maatregelen worden aangenomen, maar structurele veranderingen uitblijven}

\section{Internationale onderhandelingen creëren mogelijkheden én beperkingen}

Een deel van de verklaring waarom EU-overheden het wel eens werden over een aantal wetsvoorstellen ligt bij internationale onderhandelingen binnen de OESO die tegelijkertijd plaatsvonden. Op initiatief van de G20 in 2012 startte de OESO, met haar 36 leden, het BEPS-project, een internationaal gecoördineerde aanpak tegen grondslaguitholling en winstverschuiving (OECD, 2013). In 2015 werden voor de vijftien eerder geformuleerde actiepunten overeenstemmingen gepresenteerd, variërend van aanbevelingen tot minimumstandaarden. Daarna werd de rest van de internationale gemeenschap, zonder stemrecht te hebben gehad in de onderhandelingen, erbij betrokken. Ze kregen de keuze: meedoen of niet. Sindsdien is door verschillende nationale overheden een aantal maatregelen gerelateerd aan de vijftien actiepunten ingevoerd. Zoals gezegd, is de richtlijn ter bestrijding van belastingontwijking (ATAD) de gezamenlijke EU-implementatie van het BEPS-project. De EU-richtlijn is daarmee een direct gevolg van mondiale ontwikkelingen. Binnen de kaders van het BEPS-project werd ook $\mathrm{CbC}$ reporting besproken én overeengekomen. Het is voor het eerst dat transnationale ondernemingen verplicht worden deze informatie jaarlijks op te stellen. De overeenkomst beperkt zich echter tot gegevensuitwisseling tussen belastingdiensten; de informatie wordt dus niet publiek. Deze beperking heeft effect gehad op het politieke proces in de $\mathrm{EU}$ en heeft de mogelijkheden voor publicatie van $\mathrm{CbC}$-rapportages binnen de EU verkleind. Het is daarom van belang wat er in internationale context precies werd overeengekomen, en wat niet. Zonder deze internationale politieke processen had bovenstaand overzicht er waarschijnlijk anders uitgezien, en bovendien hebben de uitkomsten op het niveau van de EU op hun beurt ook de internationale context beïnvloed.

Controverses in de media en de competitie-rulings van Vestager: het belang van individuele bedrijfscasus

Een tweede verklaring voor het aannemen van gerichte maatregelen - terwijl structurele verandering uitblijft - is een aantal controverses die elkaar opvolgden, dankzij de moed van klokkenluiders en het werk van onderzoeksjournalisten. De Luxemburg Leaks legden bloot hoe de praktijk van rulings in het werk ging, met 
name in - de naam verklapt het al - Luxemburg (International Consortium of Investigative Journalists, 2014). Het onderzoeksjournalistieke project bestudeerde duizenden tax rulings, onderhandeld door het bedrijf PricewaterhouseCoopers $(\mathrm{PwC})$ in de periode 2002-2010 namens zijn klanten in Luxemburg. Ook in Nederland leverde deze controverse veel debat op. Daaropvolgende 'leaks', zoals SwissLeaks, Offshore Leaks en de Panama Papers, hadden verschillende aandachtsgebieden: een specifieke nationale context, een specifiek belastingvoordeel of een bepaalde industrie. Deze controverses hadden gemeen dat ze de rol van zowel nationale overheden als specifieke beroepsgroepen - zoals belastingadviseurs en accountants - in het opzetten en in stand houden van een offshoresysteem blootlegden. Bovendien werd aan de hand van individuele gevallen - van zowel bedrijven als personen - voor het eerst voor een breder publiek bekend hoe belastingontwijking en andere fraudezaken precies werken. Praktijken die voorheen (en nog steeds) onderbelicht zijn en het beste werken onder een sluier van geheimhouding. Twee van de richtlijnen die in de vorige pararaaf besproken werden, illustreren het directe effect van de mediacontroverses. Het wetsvoorstel voor de uitwisseling van rulings volgde vier maanden na de publicatie van de Luxembourg Leaks. In juni 2017, in het voorstel dat tussenpersonen ('intermediaries') verplicht bepaalde fiscale constructies te melden, refereerde de Commissie expliciet aan de Panama Papers (COM(2017)335). Hierin werd door het internationale collectief van onderzoeksjournalisten de rol van tussenpersonen zoals corporate service provider Mossack Fonseca blootgelegd (International Consortium of Investigative Journalists, 2016).

Een andere actor die controversiële gevallen van belastingontwijking belichtte, was de Europese Commissie, of specifieker het directoraat generaal (DG) voor Competitie, met Margrethe Vestager als Eurocommissaris. Binnen dit DG is een specifieke werkgroep opgezet die zaken onderzoekt waarin lidstaten mogelijk illegale staatssteun hebben gegeven in de vorm van belastingvoordelen aan bedrijven (Europese Commissie, 2018d). In verschillende gevallen heeft de Europese Commissie Ierland, Luxemburg, Nederland en België schuldig bevonden aan illegale staatssteun en opgelegd dat de gedolven belastinginkomsten alsnog geïnd worden. Het gaat om bekende en voornamelijk Noord-Amerikaanse bedrijven: Apple, Amazon, Starbucks, Nike, maar ook ENGIE, Fiat en Inter IKEA. Dit betekent niet dat de Commissie zich via deze weg heeft ontpopt als machtige progressieve kracht voor rechtvaardige belastingen. De neoliberale drijfveer is het voorkomen en bestrijden van concurrentievervalsing op de Europese interne markt. Belastingvoordelen die slechts aan een aantal bedrijven worden verleend, zijn in strijd met dit doeleinde en worden vanuit dat perspectief als oneerlijk en illegaal beoordeeld.

\section{Institutionele dynamiek en politieke machtsverhoudingen in de EU}

DG Competitie is een machtiger speler binnen de Commissie dan DG Belastingen en Douane-unie (TAXUD), dat verantwoordelijk is voor de meeste dossiers die tot nu zijn besproken. De besluitvormingsprocedure op belastingdossiers is niet supranationaal, een uitzondering vergeleken met competitie en andere beleidsgebieden gerelateerd aan de interne markt. Vastgelegd in het verdrag betreffende de 
werking van de EU is unanimiteit binnen de Raad vereist wanneer het zowel indirecte als directe belastingen betreft (artikelen 113 en 115). De rol van het Parlement is, anders dan wanneer de gewone wetgevingsprocedure wordt gevolgd, beperkt tot consultatie. Dat betekent dat het Parlement een gezamenlijke positie adopteert, maar niet in onderhandelingen treedt met de Commissie en de Raad. De Raad kan, in zijn besluitvorming, dit advies ook naast zich neerleggen. De institutionele dynamiek en onderliggende machtsverhoudingen vormen een derde deel van de verklaring waarom gerichte maatregelen zijn aangenomen, maar structurele verandering uitblijft.

Unanimiteit zorgt ervoor dat macht op het gebied van belastingen grotendeels geconcentreerd is in de Raad. Bovendien kan er daarbinnen één of een kleine groep lidstaat-vertegenwoordiger(s) de macht naar zich toetrekken door het tegenhouden van wetgeving en samenwerking die door een meerderheid gesteund wordt. Buiten de ECOFIN - de Raad van ministers van Financiën, waar de meeste belastingzaken op de agenda staan - is er ook de zogenaamde Gedragscodegroep. Dit is een werkgroep, bestaande uit vertegenwoordigers van de nationale ministeries van Financiën, die de volgende in 1997 overeengekomen politieke afspraak beschermen: een gedragscode inzake de belastingregeling voor ondernemingen 'met als doel schadelijke belastingconcurrentie tegen te gaan' (Europese Raad, 2018). De Gedragscodegroep neemt geen hard law aan, maar creëert zogeheten soft law. Het werk van de Gedragscodegroep wordt gekenmerkt door een problematisch gebrek aan transparantie (Nouwen, 2017).

In zowel de ECOFIN-opstelling van de Raad als in de Gedragscodegroep is het een obstakel dat een aantal lidstaten bekende belastingparadijzen zijn. In studies naar 'agressieve belastingplanningsindicatoren' concludeert de Commissie dat lidstaten als Nederland, Cyprus, Ierland, Malta en Luxemburg hoog scoren vergeleken met andere op een aantal indicatoren en daarom 'lijken te worden blootgesteld aan agressieve fiscale planningsstructuren' (Europese Commissie, 2017). Oftewel: het vigerende beleid trekt belastingontwijkingsstructuren aan. Op ongekende wijze werden onder andere deze lidstaten daar in maart 2018 direct op aangesproken in een speech door Eurocommissaris Moscovici (Europese Commissie 2018e)..$^{9}$ In het beleid van deze overheden klinken de belangen door van het transnationale bedrijfsleven en de beroepsgroepen van adviseurs, accountants, trustkantoren en advocaten die belastingontwijking en -ontduiking faciliteren. Dit is bijvoorbeeld te zien in de beslissing van de EU-lidstaten die door DG Competitie werden gedwongen tot terugvordering van belastingbetalingen (van Apple, Amazon et cetera) wegens illegale staatssteun. Zonder uitzondering zijn de Ierse, Belgische, Luxemburgse en Nederlandse overheden in beroep gegaan tegen de beslissingen van de Commissie. Onder het mom van het beschermen van fiscale soevereiniteit gaven ze prioriteit aan de afspraken die zij maakten met transnationale bedrijven over het innen van de gederfde belastinginkomsten, die varieerden van tientallen miljoenen tot 13 miljard euro in het geval van Apple in Ierland..$^{10}$

Unanimiteit in de Raad op belastinggebied dat de - soms fictionele en zelfs paradoxale - idee van fiscale soevereiniteit van EU-lidstaten moet veiligstellen, maakt het blijkbaar mogelijk om een aantal gerichte maatregelen tegen belasting- 
ontwijking te nemen, maar geeft geen ruimte voor structurele verandering. Vanuit dat perspectief kunnen we ook de uitspraken begrijpen van huidig Commissievoorzitter en voormalig premier van belastingparadijs Luxemburg Juncker tijdens de 'Staat van de Unie' in 2018, getiteld De tijd is gekomen voor Europese soevereiniteit: 'Ik meen dat we voor bepaalde zaken op belastinggebied ook moeten kunnen besluiten met gekwalificeerde meerderheid' (Europese Commissie, 2018f). In januari 2019 communiceerde de Commissie haar idee voor een stapsgewijze ontwikkeling van besluitvorming bij unanimiteit naar gekwalificeerde meerderheid (Europese Commissie, 2019). Dit is een 'niet-wetgevende' communicatie; een wetgevend voorstel zal pas door de nieuwe Commissie, na de Europese Parlementsverkiezingen, kunnen worden opgesteld.

De Commissie heeft duidelijk supranationale wensen op belastinggebied dat formeel competentie is van de lidstaten. Is dat in het belang van de strijd tegen belastingontwijking, en daarmee een stap richting structurele wenteling in het vigerende beleid? Laten we kort terugkeren naar de voorstellen voor harmonisatie in de vennootschapsbelasting. Hier heeft de Commissie uit strategische overwegingen expliciet besloten het voorstel op te knippen in twee stappen. Bovendien heeft het gekozen voor een re-branding: waar het idee voor harmonisatie en consolidatie eerder werd ontwikkeld en gepresenteerd als de volgende stap naar een volledige interne markt, wordt het nu ook in de strijd gegooid als hét wapen tegen agressieve belastingplanning en schadelijke belastingcompetitie. Echter, implementatie van beide voorstellen zal leiden tot een geïntensiveerde 'race naar de bodem' in termen van belastingtarieven - aangezien dit het enige overgebleven instrument is waarmee nationale overheden nog kunnen concurreren. Dit kan tot zeer lage vennootschapsbelastingtarieven in de EU leiden, en tot een verdere ontwikkeling van de lastenverschuiving van (mobiel) kapitaal naar arbeid. Het narratief van de aanpak van 'agressieve belastingplanning' moet daarom niet aanleiding zijn om alle voorstellen en richtlijnen te bestempelen als een progressieve en radicale verandering weg van 'de neoliberale modus van Europese integratie' (Oberndorfer, 2015, 186).

Het afschaffen van unanimiteit, zoals voorgesteld door de Commissie, zou zorgen voor een invloedrijkere rol van het Parlement. Binnen de institutionele mogelijkheden hebben progressieve krachten in het Parlement de afgelopen jaren duidelijk de grenzen opgezocht. Er zijn naar aanleiding van de verschillende mediacontroverses in totaal vier bijzonder parlementaire commissies opgericht om problematiek op het gehele spectrum van belastingontwijking tot -ontduiking te onderzoeken. Op basis van onder andere studies, publieke hoorzittingen en landenbezoeken hebben de verschillende commissies door de jaren heen aanbevelingen gedaan aan zowel de Commissie als de Raad die verder gaan dan de meeste richtlijnen en voorstellen die aan bod zijn gekomen in voorgaande secties. In maart 2019 benoemde het Parlement zelfs voor het eerst vijf belastingparadijzen in de EU, waaronder Nederland (NOS 2019). De macht van het Parlement is echter beperkt en daarmee ook de democratische controle op besluitvormingsprocedures binnen en tussen de Raad en de Commissie. Het bovengenoemde gebrek aan transparantie verergert dit. Of er in de Raad nu besluiten worden genomen op basis van unanimiteit of gekwalificeerde meerderheid, het Parlement moet 
meer zicht en invloed krijgen op deze politieke processen. De democratische legitimiteit van belastingbeleid blijft anders gering.

\section{Onderliggende machtsverhoudingen: twee kanten van het spectrum}

Politieke machtsverhoudingen binnen de EU staan niet op zichzelf, maar zijn een articulatie van bredere machtsverhoudingen. Aan de ene kant van dit spectrum pleit het georganiseerde bedrijfsleven voor regulering die dubbele belasting voorkomt en een gelijk speelveld creëert. Andere regulering wordt vaak wantrouwig tegemoetgezien uit angst voor 'overkill' (situaties waarin geen sprake is van ontwijking en die toch worden getroffen door nieuwe maatregelen) en ineffectiviteit. Het beschermen van vestigingsklimaat en het tegenhouden van kapitaalvlucht worden als kernargumenten gebruikt om een (strenge) aanpak van belastingontwijking tegen te gaan. Dat geldt ook voor regulering om transparantie te vergroten, zoals in het voorbeeld van $C b C$ reporting hierboven. Deze argumenten zijn ook terug te zien in de standpunten die door lidstaten naar voren worden gebracht, bijvoorbeeld het Nederlandse kabinetsstandpunt betreffende de uitkomst van het BEPS-project van de OESO in 2015. De internationaal overeengekomen anti-belastingontwijkingsmaatregelen werden direct gerelateerd aan 'een vooruitblik op Nederlands fiscaal vestigingsklimaat' (Rijksoverheid, 2015).

Aan de andere kant zien we 'de nieuwe politiek van mondiale tax justice' (Elbra \& Eccleston, 2018). Onder deze noemer zijn verzameld non-profitorganisaties (ngo's), vakbonden, activisten en expertnetwerken. De opkomst van deze tax justice-beweging is relatief recent, en onderzoek naar haar invloed nog recenter (Dietsch \& Rixen, 2014; Elbra \& Eccleston, 2018). Echter, onderzoek laat zien dat gemeenschappelijke doelstellingen van gerechtigheid - vaak vertaald in meer transparantie en een eerlijk mondiaal belastingsysteem waarin multinationals hun fair share betalen - zijn terug te zien in het politieke debat en concrete ontwikkelingen in beleid en besluitvorming. Seabrooke en Wigan beargumenteren bijvoorbeeld dat zonder de ideeën en de rol van een ngo zoals het (Britse/internationale) Tax Justice Network CbC reporting nooit zo op de Europese en internationale agenda had gestaan (Seabrooke \& Wigan, 2016).

\section{Conclusie en vooruitblik naar de verkiezingen}

De vorige paragrafen laten zien dat rechtvaardigheidsargumenten van de tax justice-beweging hun weerslag hebben op beleidsinitiatieven en -discussies. De maatregelen die zijn geïnitieerd in de afgelopen vijf jaar moesten - volgens de Commissie - de publieke transparantie vergroten, gegevensuitwisseling verbeteren, bekende mazen in de belastingwet dichten, belastingparadijzen aanpakken, digitale activiteiten beter belasten en, tot slot, belastingsystemen in de EU harmoniseren. Zoals aangetoond, is een aantal gerichte maatregelen aangenomen die specifieke constructies aanpakken of voor gegevensuitwisseling zorgen op een bepaald dossier. Structurele veranderingen of verdergaande publieke transparantie blijven uit. Invoering van een EU-minimumtarief in de vennootschapsbelasting haalt niet eens de onderhandelingstafel. De maatregelen maken geen einde 
aan schadelijke belastingcompetitie tussen EU-lidstaten. Het glas is daarmee half leeg. Veranderingen hebben wel degelijk plaatsgevonden - het glas is niet leeg en er zijn verschuivingen te zien in het fiscale debat waar nieuwe en invloedrijke stakeholders zich laten horen. De beweging in onderliggende machtsverhoudingen heeft zich echter, vooralsnog, niet gemanifesteerd in structurele verandering in het EU-belastingbeleid. Voor een vol glas is meer verandering nodig in de manier waarop winsten van transnationale bedrijven belast worden. Nieuw beleid en nieuwe wetgeving moeten verandering brengen in de fundamenten die daaraan ten grondslag liggen, in plaats van specifieke mazen in wetgeving dichten of zich te veel laten leiden door actuele kwesties. De verhoudingen tussen belasting op kapitaal en arbeid moeten daarbij nadrukkelijker in ogenschouw worden genomen. Een probleem is het gebrek aan politieke wil binnen de EU, met name bij die lidstaten waarvan het beleid belastingontwijking door transnationale bedrijven faciliteert. De besluitvormingsprocedures in de EU stellen deze lidstaten in staat verandering tegen te houden onder een sluier van geheimhouding. Deze processen moeten, om democratische legitimiteit van beleid en proces te garanderen, transparanter worden. Onderzoek naar deze politieke processen is er nauwelijks. Het recentste kwalitatieve onderzoek naar EU-belastingbeleid is van eind jaren negentig (Radaelli, 1997). Met name onderzoek naar de invloed van verschillende actoren op de ontwikkeling van belastingbeleid zou relevant inzicht bieden in (verschuivingen van) onderliggende machtsverhoudingen en structuren waaraan deze zijn onderworpen.

Zoals aangegeven, zijn de huidige bevoegdheden van het Parlement op het gebied van belasting minimaal. In die positie heeft en neemt een aantal progressieve krachten in het Parlement wel de mogelijkheid om verdergaande voorstellen te doen. Zo pleit het bijvoorbeeld voor een Europees minimumtarief in combinatie met de geharmoniseerde en geconsolideerde grondslag (CCCTB). De kans dat politieke onderhandelingen over de dossiers die voor structurele verandering en publieke transparantie kunnen zorgen worden afgesloten vóór de verkiezingen in mei 2019, is nihil. De uitkomst van de verkiezingen zal daarom zonder twijfel van invloed zijn op de toekomst van de aanpak van belastingontwijking in de EU. Kritische en progressieve krachten in het Parlement zijn broodnodig op een gebied waar de Commissie zich gelegitimeerd voelt meer te interveniëren omdat 75 procent van de Europese burgers dat graag zou zien (Europees Parlement, 2016). De uitdagende taken bestaan niet alleen uit het opvoeren van politieke druk voor meer structurele veranderingen om een halt te roepen aan belastingontwijking. Het Parlement moet ook een taak hebben in het blootleggen en problematiseren van immer aanhoudende belastingcompetitie tussen EU-lidstaten, ten voordele van het transnationale bedrijfsleven. Het halflege glas moet voller - en daarbij is een belangrijke rol weggelegd voor zowel gevestigde, goed ingelichte als nieuwe, gemotiveerde Europarlementariërs. 


\section{Noten}

1 In dit artikel wordt belastingcompetitie beperkt tot competitie betreffende belastingtarieven. Er is beduidend minder onderzoek naar competitie waarbij instrumenten die betrekking hebben op de belastinggrondslag worden ingezet. Dat betekent niet dat overheden deze instrumenten niet veelvuldig inzetten in competitie voor mobiel kapitaal.

2 Multinationale winsten zijn als volgt gedefinieerd: 'profits made by multinational companies outside of the country where their parent is located' (p. 3).

3 De beleidsontwikkelingen die besproken worden in dit stuk zijn beperkt tot zeven recente en relevante initiatieven om belastingontwijking in de EU aan te pakken. Dat betekent dat er een aantal (aangenomen) voorstellen en initiatieven niet is besproken, inclusief de aanpassingen in de Moeder-dochterrichtlijn (Richtlijn 2014/86/EU), de voorgestelde aanpassingen in de Rente- en royaltyrichtlijn (COM(2011)714), de aanbeveling met betrekking tot tegengaan van misbruik van belastingverdragen (C(2016)271), de aanpassingen wat betreft verplichte automatische uitwisseling van inlichtingen op belastinggebied (Richtlijn 2014/107/EU), die de binnen de OESO overeengekomen de standaard voor automatische uitwisseling van financiële gegevens voor belastingdoeleinden tussen nationale overheden (de zogeheten Common Reporting Standard) invoert, en de nieuwe richtlijn betreffende mechanismen ter beslechting van belastinggeschillen in de Europese Unie (Richtlijn EU 2017/1852).

4 Op dit moment zijn de financiële rapportages geconsolideerd: de publiek beschikbare jaarverslagen van bedrijven geven een beeld van de totale operaties en daarmee gemoeide geldbedragen. Onder deze mantel van consolidatie gaat een grote hoeveelheid aan intra-groeptransacties schuil: transacties tussen de dochterondernemingen die tot dezelfde bedrijfsgroep behoren. De zogenaamde verrekenprijzen voor deze transacties - die niet plaatsvinden op 'de vrije markt' - worden bepaald aan de hand van binnen de OESO vastgestelde richtlijnen. Omdat er bij het vaststellen van deze prijzen ruimte voor interpretatie is, is het een van de meest gebruikte manieren voor het kunstmatig schuiven met winsten om zo belasting te ontwijken. Informatie hierover is zeer beperkt beschikbaar. De belastingautoriteit in een van de landen waar de bedrijfsgroep activiteiten ontplooit, krijgt wel de benodigde informatie om belasting te kunnen heffen binnen de eigen jurisdictie, maar heeft geen zicht op de belastingaangifte van de bedrijfsgroep in andere landen waar het actief is. $\mathrm{CbC}$ reporting vergroot beschikbare informatie betreffende de activiteiten die door ondernemingen in verschillende landen worden ontplooid en de eventueel belastbare winsten die er worden gegenereerd.

5 Artikel 1 lid 1 2018/822/EU: “intermediaries” means any person that carries the responsibility vis-à-vis the taxpayer for designing, marketing, organising or managing the implementation of the tax aspects of a reportable cross-border arrangement, or series of such arrangements, in the course of providing services relating to taxation.' Zie bijvoorbeeld het position paper van Tax Justice Nederland over de implementatie van ATAD I door het kabinet: www.taxjustice.nl/wp-content/uploads/sites/7/2018/ 10/Annex-Tax-Justice-NL-maatregelen-aanpak-belastingontwijking.pdf. 
6 Zie bijvoorbeeld het position paper van Tax Justice Nederland over de implementatie van ATAD I door het kabinet: www.taxjustice.nl/wp-content/uploads/sites/7/2018/ 10/Annex-Tax-Justice-NL-maatregelen-aanpak-belastingontwijking.pdf.

7 Het voorstel kreeg acht 'gele kaarten', waaronder van Nederland, Ierland, Verenigd Koninkrijk en Malta. Deze landen uitten formele bezwaren. De stekker werd pas echt uit het voorstel getrokken toen een van de grootste voorstanders, Duitsland, de handen aftrok van het voorstel.

8 German-French Common position paper on CCTB proposal, 19 juni 2018, beschikbaar via www.bundesfinanzministerium.de/Content/EN/Standardartikel/Topics/Europe/ Articles/2018-06-20-Meseberg-att2.pdf;jsessionid= B6853884EAF3DEBCFDD073DE431F8C97?_blob=publicationFile\&v=3.

9 Tekst van de speech: 'The Commission is today stressing the issue of aggressive tax planning in seven EU countries: Belgium, Cyprus, Hungary, Ireland, Luxembourg, Malta and The Netherlands. These practices that we know have the potential to undermine fairness and the level playing field in our internal market, and they increase the burden on EU taxpayers. The related country reports presented today are based on a thorough review of their tax rules and relevant factual economic indicators.'

10 Zie onder andere: Rijksoverheid, Standpunt Nederland voor Gerecht van de Europese Unie inzake Starbucks, 2 juli 2018, beschikbaar via www.rijksoverheid.nl/actueel/ nieuws/2018/07/02/standpunt-nederland-voor-gerecht-van-de-europese-unie-inzake -starbucks, en Independent, Europe 'has exceeded its powers' with Apple ruling Government, 16 december 2016, beschikbaar via www.independent.ie/business/irish/ europe-has-exceeded-its-powers-with-apple-ruling-government-35304298.html.

\section{Literatuur}

Becker, J., \& English, J. (2018). EU Digital Services Tax: A Populist and Flawed Proposal. Kluwer International Tax Blog. Beschikbaar via http://kluwertaxblog.com/2018/03/16/ eu-digital-services-tax-populist-flawed-proposal/.

Bretschger, L., \& Hettich, F. (2002). Globalisation, capital mobility and tax competition: Theory and evidence for OECD countries. European Journal of Political Economy, 18 (4): 695-716. https://doi.org/10.1016/S0176-2680(02)00115-5.

Bucovetsky, S. (1991). Asymmetric tax competition. Journal of Urban Economics, 30 (2): 167-181. https://doi.org/10.1016/0094-1190(91)90034-5.

Business Europe (2016). Public Country-by-Country Reporting. Position paper, 6 juli. Beschikbaar via www.businesseurope.eu/sites/buseur/files/media/position_papers/ ecofin/2016-07-06_cbcr_position_paper.pdf.

Crivelli, E., Mooij, R. de, \& Keen, M. (2015). Base Erosion, Profit Shifting and Developing Countries . IMF Working Papers , 15/118. https://doi.org/10.1628/ $001522116 \mathrm{X} 14646834385460$.

Davies, R., \& Voget, J. (2008). Tax competition in an expanding European Union. Working Paper Oxford University Centre for Business Taxation. https://doi.org/10.1111/1467 -9779.00129.

Devereux, M.P., Lockwood, B., \& Redoano, M. (2008). Do countries compete over corporate tax rates? Journal of Public Economics, 92 (5-6): 1210-1235. https://doi.org/10. 1016/j.jpubeco.2007.09.005. 
Dietsch, P., \& Rixen, T. (2014). Tax Competition and Global Background Justice. The Journal of Political Philosophy, 22 (2): 150-177. https://doi.org/10.1111/j.1467-9760.2012. 00419.x.

Elbra, A., \& Eccleston, R. (2018). Introduction: Business, civil society and the 'new' politics of corporate tax justice: paying a fair share? In: R. Eccleston \& A. Elbra (red.), Business, Civil Society and the 'New' Politics of Corporate Tax Justice Paying a Fair Share? Elgar Politics and Business, 1-20.

Europees Parlement (2016). Survey: people reveal their priorities for the EU (persbericht 1 juli ). Beschikbaar via www.europarl.europa.eu/news/en/headlines/eu-affairs/ 20160630STO34203/survey-people-reveal-their-priorities-for-the-eu.

Europees Parlement (2018a). Special committee on financial crimes, tax evasion and tax avoidance. Commissievergadering 27 november 2018. Beschikbaar via www.europarl. europa.eu/ep-live/en/committees/video?event=20181127-1500-COMMITTEE-TAX3.

Europees Parlement (2018b). Draft report on financial crimes, tax evasion and tax avoidance, 2018/2121(INI), november:12. Beschikbaar via www.europarl.europa.eu/sides/ getDoc.do?pubRef=-//EP//NONSGML+COMPARL+PE-627.890+01+DOC+PDF+V0// EN\&language $=\mathrm{EN}$.

Europese Commissie (2015). Tax Transparency Package. Beschikbaar via https://ec.europa. eu/taxation_customs/business/company-tax/tax-transparency-package_en.

Europese Commissie (2016a). Europese Commissie wil regels voor fiscale transparantie voor multinationals (persbericht 12 april). Beschikbaar via http://europa.eu/rapid/pressrelease_IP-16-1349_nl.htm.

Europese Commissie (2016b). Anti Tax Avoidance Package. Beschikbaar via https://ec. europa.eu/taxation_customs/business/company-tax/anti-tax-avoidance-package_en.

Europese Commissie (2017). Study on Structures of Aggressive Tax Planning Indicators. DG Taxud, Working Paper, 71: 125. Beschikbaar via https://ec.europa.eu/taxation_ customs/sites/taxation/files/taxation_papers_71_atp_.pdf.

Europese Commissie (2018a). Taxation Trends in the European Union. Data for the EU Member States, Iceland and Norway.https://doi.org/10.2778/708899.

Europese Commissie (2018b). Common EU list of third country jurisdictions for tax purposes. https://ec.europa.eu/taxation_customs/tax-common-eu-list_en, geraadpleegd op 5 december 2018.

Europese Commissie (2018c). Belasting digitale economie: voorstellen van de Commissie om alle internetbedrijven eerlijk te belasten in de $E U$ (persbericht 21 maart). Beschikbaar via http://europa.eu/rapid/press-release_IP-18-2041_nl.pdf.

Europese Commissie (2018d). Tax Rulings. Webpagina DG Competitie. http://ec.europa.eu/ competition/state_aid/tax_rulings/index_en.html, geraadpleegd op 25 november 2018.

Europese Commissie (2018e). Opening remarks by Commissioner Moscovici on the European Semester Winter Package (speech Pierre Moscovici). Brussel, 7 maart. Beschikbaar via http://europa.eu/rapid/press-release_SPEECH-18-1683_en.htm.

Europese Commissie (2018f). De tijd is gekomen voor Europese soevereiniteit. Staat van de Unie 2018 (speech Jean-Claude Juncker). Brussel, 12 september. Beschikbaar via https://ec.europa.eu/commission/sites/beta-political/files/soteu2018-speech_nl_2. pdf.

Europese Commissie (2019). Towards a more efficient and democratic decision making in EU tax policy. Communication COM, 8.

Europese Raad (2017). Proposal for Directive of the European Parliament and the Council amending Directive 2013/34/EU as regards disclousure of income tax information by 
certain undertakings and branches (CBCR). State of play, 10525/17 COR1. Beschikbaar via http://data.consilium.europa.eu/doc/document/ST-10525-2017-INIT/en/pdf.

Europese Raad (2018). Groep gedragscode (belastingregeling ondernemingen). Webpagina Europese Raad. https://www.consilium.europa.eu/nl/council-eu/preparatory-bodies/ code-conduct-group/, geraadpleegd op 25 november 2018.

Fortune (2019, 3 januari). The EU Can't Agree on a Digital Tax - but Silicon Valley's Still Going to Pay. Beschikbaar via http://fortune.com/2019/01/03/eu-digital-tax-silicon-valley/.

Genschel, P., \& Jachtenfuchs, M. (2011). How the European Union constrains the state: Multilevel governance of taxation. European Journal of Political Research, 50 (3): 293-314. https://doi.org/10.1111/j.1475-6765.2010.01939.x.

Genschel, P., Kemmerling, A., \& Seils, E. (2011). Accelerating Downhill: How the EU Shapes Corporate Tax Competition in the Single Market. Journal of Common Market Studies, 49 (3): 585-606. https://doi.org/10.1111/j.1468-5965.2010.02136.x.

Genschel, P., \& Rixen, T. (2015). Settling and Unsettling the Transnational Legal Order of International Taxation. In: T.C. Halliday \& G. Schaffer (red.), Transnational Legal Orders. Cambridge: Cambridge University Press, 154-184. https://doi.org/10.1017/ CBO9781107707092.006.

Genschel, P., \& Schwarz, P. (2011). Tax competition: A literature review. Socio-Economic Review, 9 (2): 339-370. https://doi.org/10.1093/ser/mwr004.

International Consortium of Investigative Journalists (2014). Luxembourg Leaks: Global Companies' Secrets Exposed. Beschikbaar via www.icij.org/investigations/luxembourgleaks/.

International Consortium of Investigative Journalists (2016). The Panama Papers: Exposing the Rogue Offshore Finance Industry. www.icij.org/investigations/panama-papers/, geraadpleegd op 4 december 2018.

Jansky, P., \& Palansky, M. (2017). Estimating the Scale of Profit Shifting and Tax Revenue Losses Related to Foreign Direct Investment (IES Working Paper nr. 25/2017). Praag.

Leibrecht, M., \& Hochgatterer, C. (2012). Tax competition as a cause of falling corporate income tax rates: A survey of empirical literature. Journal of Economic Surveys, 26 (4): 616-648. https://doi.org/10.1111/j.1467-6419.2010.00656.x.

Murphy, R. (2012). Closing the European Tax Gap. A report for Group of the Progressive Alliance of Socialists \& Democrats in the European Parliament. Tax Research UK. Beschikbaar via www.socialistsanddemocrats.eu/sites/default/files/120229_richard_murphy_ eu_tax_gap_en.pdf.

NOS, 'Nederland is een belastingparadijs', 26 maart 2019, https://nos.nl/artikel/2277661nederland-is-een-belastingparadijs.html.

Nouwen, M. (2017). The European Code of Conduct Group Becomes Increasingly Important in the Fight Against Tax Avoidance: More Openness and Transparency is Necessary. Intertax, 45 (2): 138-149.

Oberndorfer, L. (2015). From New Constitutionalism to Authoritarian Constitutionalism: New Economic Governance and the State of European Democracy. In: Asymmetric Crisis in Europe and Possible Futures: Critical Political Economy and Post-Keynesian Perspectives, p. 276. https://doi.org/10.4324/9781315764009.

OECD (2013). Action plan on base erosion and profit shifting. Action Plan on Base Erosion and Profit Shifting (vol. 9789264202). https://doi.org/10.1787/9789264202719-en.

Palan, R., Murphy, R., \& Chavagneux, C. (2009). Tax Havens - How Globalization Really Works. Ithaca.

Panayi, C.H. (red.) (2013). European Union Corporate Tax Law. Cambridge: Cambridge University Press. 
Picciotto, S. (2011). Regulating global corporate capitalism. Cambridge: Cambridge University Press.

Picciotto, S. (2012). Towards Unitary Taxations of Transnational Corporations. Tax Justice Network, december.

Radaelli, C. (1997). The Politics of Corporate Taxation in Europe. Knowledge and international policy agendas. Londen: Routledge.

Radaelli, C. (1999). Harmful Tax Competition in the EU: Policy Narratives and Advocacy Coalitions. Journal of Common Market Studies, 37 (4): 661-682.

Redoano, M. (2014). Tax competition among European countries. Does the EU matter? European Journal of Political Economy, 34: 353-371. https://doi.org/10.1016/j.ejpoleco. 2014.02.006.

Reuters (2017, 9 september). France, Germany, Italy, Spain seek tax on digital giants' revenues Beschikbaar via https://www.reuters.com/article/us-eu-tax-digital/francegermany-italy-spain-seek-tax-on-digital-giants-revenues-idUSKCN1BKOHX.

Rijksoverheid (2015). Appreciatie uitkomst BEPS-project en vooruitblik Nederlands fiscaal vestigingsklimaat. Kamerstuk IZV/2015/657 M. Beschikbaar via www.rijksoverheid.nl/ documenten/kamerstukken/2015/10/05/brief-based-erosion-profit-shifting.

Roland, A. (2018). European Corporate Tax Policy since the Crisis (Working Paper Series 'Comparative Governance', nr. 3). Beschikbaar via https://pub.uni-bielefeld.de/ download/2931592/2931593/WP_EU_taxpol_Roland.pdf.

Seabrooke, L., \& Wigan, D. (2016). Powering ideas through expertise: professionals in global tax battles. Journal of European Public Policy, 23 (3): 357-374. https://doi.org/10. 1080/13501763.2015.1115536.

Streek, J.L. van de (2017). De geherlanceerde CCTB/CCCTB-voorstellen; nu wél een schot in de roos? Weekblad Fiscaal Recht, 7184: 391-401. https://doi.org/10.1109/APEC. 2016.7468359.

Tørsløv, T.R., Wier, L.S., \& Zucman, G. (2018). The missing profits of nations (NBER Working Paper Series, nr. 24701). Cambridge, Mass. Beschikbaar via https://gabrielzucman.eu/files/TWZ2018.pdf .

UNCTAD (2015). World Investment Report 2015: Reforming International Investment Governance. Genève. Beschikbaar via http://unctad.org/en/PublicationsLibrary/wir2015_en. pdf.

Wilson, J.D. (1991). Tax competition with interregional differences in factor endowments. Regional Science and Urban Economics, 21 (3): 423-451. https://doi.org/10.1016/0166 -0462(91)90066-V.

Zodrow, G. (2003). Tax competition and tax coordination in the European Union. International Tax and Public Finance, 10 (6): 651-671. https://doi.org/10.1023/A: 1026377819946.

Zodrow, G., \& Mieszkowski, P. (1986). Pigou, Tiebout, Property Taxation, and the Underprovision of Local Public Goods. Journal of Urban Economics, 19 (3): 356. https://doi. org/10.1016/0094-1190(86)90048-3. 